\title{
Kajian Perubahan Fisik Spasial Kawasan Urban Fringe di Kecamatan Ampenan Kota Mataram
}

\author{
Ima Rahmawati Sushanti, Nahrul Hayat Imansyah*, \\ Febrita Susanti, Yusril Ihza Mahendra, dan Rasyid Ridha \\ Program Studi Perencanaan Wilayah dan Kota, Universitas Muhammadiyah Mataram, Kota Mataram \\ *aroel.iman@gmail.com
}

\section{INFO ARTIKEL}

Riwayat Artikel:

Diterima: 12-07-2018

Disetujui: 28-07-2018

\section{Kata Kunci:}

Spasial

Landuses

Konsistensi

Evaluasi

Konversi

\begin{abstract}
ABSTRAK
Abstrak: Penelitian ini bertujuan mengetahui sejauh mana perubahan fisik yang terjadi akibat adanya perkembangan Kota Mataram dari tahun 2010 sampai tahun 2017 dan mengevaluasi implementasi RTRW Kota Mataram terhadap perubahan fisik spasial Kawasan Urban Fringe Kota Mataram khususnya di Kecamatan Ampenan. Metode penelitian menggunakan pendekatan deskriptif kualitatif- kuantitatif dengan menggunakan analisis matriks konsistensi dan dikombinasikan dengan analisis spasial untuk membantu dalam analisa pemetaan. Hasil dari kajian luasan perubahan fisik spasial Kecamatan Ampenan dari tahun 2010 sampai tahun 2017 adalah $\pm 80,49 \mathrm{Ha}$ atau 8,59\% dari total luas wilayahnya, dimana konversi lahan yang dominan terjadi yaitu berupa lahan pertanian (sawah) berubah fungsi menjadi lahan terbangun perkotaan (permukiman dan terbangun non permukiman). Sedangkan hasil evaluasi konflik ruang antara RTRW dengan Penggunaan Lahan pada tahun 2010 dan 2017, diperloleh bahwa pada tahun 2010 terdapat $47.61 \mathrm{Ha}(5.04 \%)$ yang bersifat bertentangan/inkonsisten, $123.38 \mathrm{Ha}$ (13.06 \%) yang bersifat nertal, dan $773.93 \mathrm{Ha}(81.90 \%)$ yang bersifat sesuai/konsisten. Sedangkan pada tahun 2017 terdapat $75.41 \mathrm{Ha}$ (7.98 \%) yang bersifat bertentangan/inkonsisten, $75.70 \mathrm{Ha}(8.01 \%)$ yang bersifat netral dan $793.81 \mathrm{Ha}$ (19.88 \%) yang bersifat sesuai/konsisten. Sehingga dapat disimpulkan bahwa, secara umum implementasi kegiatan pemanfaatan serta pengendalian ruang di Kecamatan Ampenan masih dikategorikan dalam kondisi aman dan berjalan dengan cukup baik.
\end{abstract}

\begin{abstract}
This study aims to determine the extent to which physical changes that have occurred due to the development of Mataram City from 2010 to 2017 and evaluate the implementation of the Mataram City Spatial Plan on the spatial changes in Mataram Urban Fringe Areas, especially in Ampenan District. The research method used a qualitativequantitative descriptive approach using consistency matrix analysis and combined with spatial analysis to assist in mapping analysis. The results of the study of the extent of the spatial physical change of Ampenan Subdistrict from 2010 to 2017 are $\pm 80.49 \mathrm{Ha}$ or $8.59 \%$ of the total area, where the dominant land conversion occurs namely in the form of agricultural land (function) to become urban built land (settlements and non-residential buildings). While the results of the evaluation of space conflicts between the RTRW with Land Use in 2010 and 2017, it was obtained that in 2010 there were $47.61 \mathrm{Ha}$ (5.04\%) which were contradictory / inconsistent, $123.38 \mathrm{Ha}$ (13.06\%) which was non-existent, and $773.93 \mathrm{Ha}$ (81.90\%) which is consistent / consistent. Whereas in 2017 there were $75.41 \mathrm{Ha}$ (7.98\%) which were contradictory I inconsistent, $75.70 \mathrm{Ha}$ (8.01\%) which were neutral and $793.81 \mathrm{Ha}$ (19.88\%) which were consistent / consistent. So it can be concluded that, in general, the implementation of space utilization and control activities in Ampenan Subdistrict is still categorized as safe and running fairly well.
\end{abstract}

\section{A. LATAR BELAKANG}

Daerah pinggiran kota (Urban Fringe) sebagai suatu wilayah peluberan kegiatan perkembangan kota telah menjadi perhatian banyak ahli di berbagai bidang ilmu seperti geografi, sosial, dan perkotaan sejak tahun 1930an saat pertama kali istilah Urban Fringe dikemukakan dalam literatur. Besarnya perhatian tersebut terutama tertuju pada berbagai permasalahan yang diakibatkan oleh proses ekspansi kota ke wilayah pinggiran yang berakibat pada perubahan fisikal misal perubahan tata guna lahan, demografi, keseimbangan ekologis serta kondisi sosial ekonomi [1].

Salah satu isu yang perlu mendapat perhatian adalah menyangkut fenomena daerah pinggiran kota dan proses perubahan spasial dan sosial ekonomi di daerah ini. Daerah pinggiran kota (Urban Fringe) didefinisikan sebagai daerah pinggiran kota yang berada dalam proses transisi dari daerah perdesaan menjadi perkotaan. Sebagai daerah transisi, daerah ini berada dalam tekanan 
kegiatan-kegiatan perkotaan yang meningkat yang berdampak pada perubahan fisikal termasuk konversi lahan pertanian dan non pertanian dengan berbagai dampaknya.

Menurut Howard pada akhir abad ke 19, diantara daerah perkotaan, daerah perdesaan, dan daerah pinggiran kota, ternyata daerah pinggiran kota memberikan peluang paling besar untuk usaha-usaha produktif maupun peluang paling menyenangkan untuk bertempat tinggal. Manusia sebagai penghuni daerah pinggiran kota selalu mengadakan adaptasi terhadap lingkungannya. Adaptasi dan aktivitas ini mencerminkan dan juga mengakibatkan adanya perubahan sosial, ekonomi, kultural, dan lain-lain [2].

Beberapa kecamatan yang masuk dalam administrasi Kota Mataram masih menampakan ciri kawasan Urban Fringe. Salah satunya yaitu di Kecamatan Ampenan. Dimana kawasan ini umumnya memiliki ciri-ciri perbandingan landuse lebih dari $60 \%$ berupa urban landuse dan kurang dari 40\% rural landuse [3]. Hal tersebut merupakan suatu proses perembetan fisik kekotaan ke arah luar dari ciri zona rural menjadi zona urban yang merupakan suatu keniscayaan yang akan terjadi di daerah pinggiran kota. Kegiatan konversi lahan pertanian pun akan terus bertambah sebagai akibat semakin berkurangnya lahan di kawasan inti kota.

Pola fisik (ruang) kota tentunya tidak boleh sertamerta dibiarkan berkembang dengan sendirinya. Hal ini akan sangat berdampak tidak teraturnya manajemen ruang kota. Tanpa adanya penataan ruang yang tepat, akan sangat berdampak pada menurunnya kualitas hidup baik manusia maupun lingkungan tempat hidupnya. Oleh karena itu, perkembangan pola fisik kota harus di tata dan diatur agar terwujud keharmonisan, keterpaduan serta dapat menjadi pelindung fungsi ruang dan pencegahan dampak negatif terhadap lingkungan akibat pemanfaatan ruang. Sehingga, dari kecenderungan pola penggunaan lahan yang terjadi, dapat diamati kesesuaiannya dan kesenjangannya dengan Rencana Tata Ruang Wilayah yang berlaku.

Berdasarkan latar belakang dan permasalahan di atas maka tujuan dari penelitian ini adalah untuk mengetahui perubahan fisik spasial kawasan Urban Fringe sekaligus mengevaluasi hasil implementasi RTRW kota mataram terhadap perubahan fisik spasial kawasan Urban Fringe di kecamatan ampenan Kota Mataram.

\section{B. METODE PENELITIAN}

Metode analisis data dengan analisis spasial dan deskriptif kualitatif-kuantitatif yaitu untuk mengidentifikasi perubahan fisik spasial serta mengevaluasi (konsistensi/inkonsistensi) pemanfatan ruang dengan arahan RTRW Kota Mataram.

\section{Analisa perubahan fungsi lahan}

Perubahan fungsi lahan dapat dilakukan dengan cara membandingkan penggunaan lahan tahun 2010 dengan penggunaan lahan eksisting yaitu dengan melakukan interpretasi Peta Citra tahun 2010 dan Peta Citra tahun 2017 dengan disertai observasi dilapangan (survei primer). Sehingga dari hasil analisis ini dapat diketahui pola dan jenis perubahan (konversi) lahan. Analisis ini menggunakan alat bantu ARCGIS 10.3.

\section{Analisa besaran perubahan fungsi lahan}

Setelah diketauhi pola perubahan penggunaan lahan berdasarkan hasil analisis sebelumnya, selanjutkan akan dihitung besar perubahan penggunaan lahan tahun 2010, akan dibandingkan dengan kondisi eksisting (tahun 2017). Analisis ini menggunakan alat bantu berupa ARCGIS 10.3 dengan perintah "Calculator Geometri" dan analisis statistik dengan bantun Microsoft Excel 2013.

\section{Analisa Konflik Ruang (konsistensi/ \\ inkonsistensi).}

Konflik ruang dapat diidentifikasi dengan menggunakan matrik konsistensi Antara RTRW dengan landuse. RTRW dinilai konsistensi jika terdapat kesesuaian diantara keduanya, dan inkonsistensi jika pemanfaatan ruang tidak sesuai dengan RTRW. Penilaian atau matriks konsistensi dapat dilihat pada Tabel 1 dan dibantu dengan analisis spasial berupa overlay antara peta/data Rencana Pola Ruang/RTRW Kota Mataram dengan landuse.

Tabel 1

Matriks Konsistensi dan Konflik Ruang

\begin{tabular}{|c|c|c|c|c|c|c|c|c|}
\hline \multirow{2}{*}{ RTRW } & \multicolumn{8}{|c|}{ Landuse } \\
\hline & Htn & Swh & $\mathrm{Tgl}$ & Prk & $\mathrm{Pkr}$ & Prkm & $\mathrm{Ba}$ & Ltb \\
\hline \multicolumn{9}{|l|}{ Kaw. Lindung } \\
\hline Hutan lindung & + & 0 & 0 & 0 & - & - & + & + \\
\hline Resapan Air & + & + & 0 & - & - & - & ++ & - \\
\hline $\begin{array}{l}\text { Rawan } \\
\text { bencana }\end{array}$ & + & - & - & - & - & - & - & - \\
\hline \multicolumn{9}{|l|}{$\begin{array}{l}\text { Kawasan } \\
\text { Budidaya }\end{array}$} \\
\hline Pertanian & 0 & ++ & 0 & - & - & - & 0 & - \\
\hline Perkebunan & - & - & + & ++ & + & - & + & - \\
\hline Perikanan & 0 & + & - & - & 0 & - & + & - \\
\hline $\begin{array}{l}\text { Hutan } \\
\text { Produksi }\end{array}$ & ++ & - & - & - & - & - & 0 & - \\
\hline $\begin{array}{l}\text { Pertambangan } \\
\text { (G-C) }\end{array}$ & - & - & - & - & 0 & - & - & - \\
\hline Permukiman & - & 0 & 0 & 0 & 0 & ++ & 0 & + \\
\hline Industri & - & - & 0 & - & + & - & + & + \\
\hline Pariwisata & + & - & 0 & 0 & + & + & + & + \\
\hline $\begin{array}{l}\text { Bisnis } \\
\text { Perdagangan }\end{array}$ & - & - & 0 & + & + & + & - & + \\
\hline \multicolumn{9}{|c|}{$\begin{array}{l}\text { Ket: } \mathrm{Htn}=\text { Hutan, } \mathrm{Swh}=\text { Sawah, Tgl=Tegalan, Prk=Perkebunan, } \\
\text { Pkr=Pekarangan, Ba=Badan Air, } \mathrm{Ltb}=\mathrm{Lahan} \text { Terbangun(non } \\
\text { permukiman) } \\
\text { += saling mendukung(konsisten), } \mathrm{o}=\text { netral, } \\
\text { - = bertentangan(inkonsisten) }\end{array}$} \\
\hline
\end{tabular}

Sumber: Muta'ali (2013) [4]

\section{HASIL DAN PEMBAHASAN}

\section{Perubahan Penggunaan Lahan}

Secara umum penggunaan lahan Kecamatan Ampenan dimanfaatkan untuk badan air, hutan, pekarangan, permukiman, sawah dan terbangun non 
permukiman yang terdiri dari fasilitas umum, industri / pergudangan, jasa komersial, perkantoran, perkuburan, perdagangan. Berdasarkan peta pemanfaatan ruang tahun 2010, secara umum masih didominasi oleh Permukiman yaitu 447.20 Ha atau 47.33 \%, dan sawah seluas $284.53 \mathrm{Ha}$ atau $30.11 \%$. Sedangkan untuk penggunaan lahan pada tahun 2017, Permukiman masih mendominasi, bahkan semakin meningkat menjadi 500,70 $\mathrm{Ha}$ atau 52,99 \%, sedangkan untuk penggunaan lahan berupa sawah justru menurun menjadi 152,11 $\mathrm{Ha}$ atau 16,10 \%. Untuk lebih jelasnya perubahan penggunaan lahan di Kecamatan Ampenan dari tahun 2010 sampai dengan tahun 2017 dapat dilihat pada Tabel 2 dan Gambar 1 dan Gambar 2.

Tabel 2

Perubahan Penggunaan Lahan di Kecamatan Ampenan Tahun 2010 - 2017

\begin{tabular}{|c|c|c|c|c|c|c|c|}
\hline \multirow{2}{*}{$\begin{array}{c}\text { Panggunaan } \\
\text { Lahan }\end{array}$} & \multicolumn{2}{|c|}{2010} & \multicolumn{2}{|c|}{2017} & \multicolumn{2}{|c|}{ Perubahan } & \multirow[b]{2}{*}{ Ket } \\
\hline & Luas(Ha) & $\%$ & Luas(Ha) & $\%$ & Luas(Ha) & $\%$ & \\
\hline Badan Air & 21.78 & 2.30 & 14.38 & 1.52 & -7.40 & 0.78 & Berkurang \\
\hline Hutan & $3 \cdot 34$ & 0.35 & 1.87 & 0.20 & -1.47 & 0.16 & Berkurang \\
\hline Pekarangan & 80.60 & 8.53 & 144.04 & 15.24 & 63.43 & 6.71 & Bertambah \\
\hline Permukiman & 447.20 & $47 \cdot 33$ & 500.70 & 52.99 & 53.50 & 5.66 & Bertambah \\
\hline Sawah & 284.53 & 30.11 & 152.11 & 16.10 & -132.41 & 14.01 & Berkurang \\
\hline $\begin{array}{l}\text { Terbangun } \\
\text { non } \\
\text { permukiman }\end{array}$ & 107.47 & 11.37 & 131.83 & 13.95 & 24.35 & 2.58 & Bertambah \\
\hline $\begin{array}{l}\text { permukiman } \\
\text { Total }\end{array}$ & 944.92 & 100.00 & 944.92 & 100.00 & & & \\
\hline
\end{tabular}

Sumber: Hasil Analisis, 2017

Berdasarkan Tabel 2, dapat dilihat bahwa penggunaan lahan yang mengalami perubahan (konversi) yang cukup tinggi yaitu berupa sawah dimana sekitar $132.41 \mathrm{Ha}$ atau 14,01\% berubah fungsi menjadi permukiman dan terbangun non permukiman. Selain itu, badan air dan hutan (bakau) pun mengalami perurabahan fungsi dimana dengan besaran perubahan rata-rata $<1 \%$ Hal ini menunjukan bahwa semakin lama intensitas lahan terbangun di daerah perkotaan semakin meningkat.

Peningkatan intensitas lahan terbangun tentunya akan memiliki dampak terutama dampak terhadap lingkungan. Menurut Rosul, proses penambahan intensitas lahan terbangun akan mengakibatkan semakin berkurangnya lahan subur produktif pertanian sehingga mengancam swasembada pangan karena terjadi perubahan peruntukan lahan pertanian menjadi lahan terbangun, berkurangnya daerah seharusnya menjadi daerah tangkapan hujan (recharge area) sebagai akibat terbatasnya lahan di pusat kota. Sehingga mengakibatkan dampak turunan seperti air larian permukaan (surface run off) semakin tinggi dan menurunnya resapan (infiltrasi), semakin banyak vegetasi yang hilang sehingga udara semakin panas, dan sumur menjadi kering pada musim kemarau karena menurunnya cadangan air di groundwater [5].

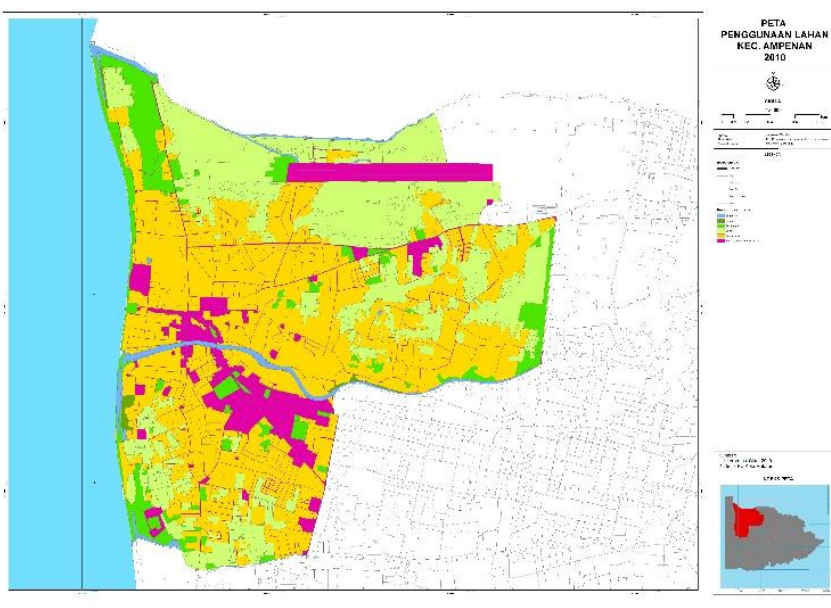

Gambar 1. Peta Penggunaan Lahan Kecamatan Ampenan Tahun 2010

(Sumber: Hasil Analisis)

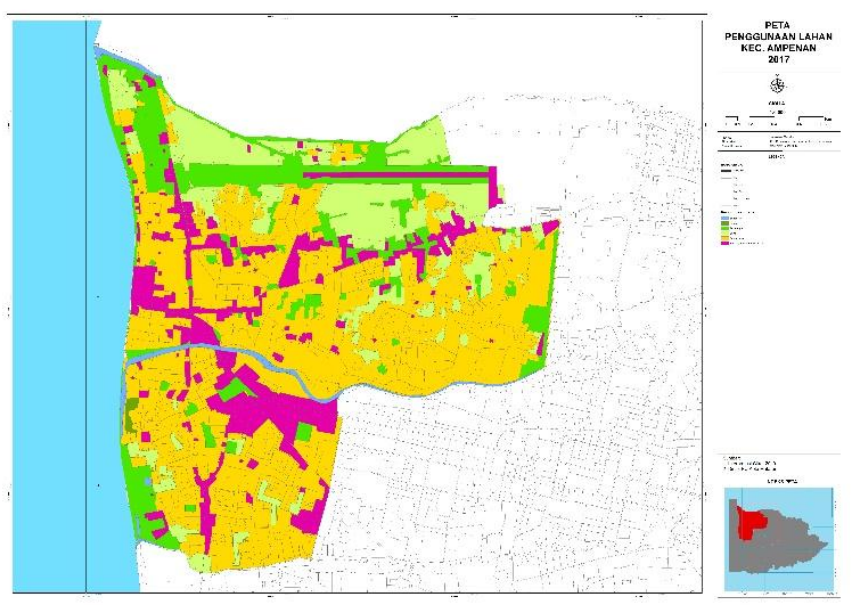

Gambar 2. Peta Penggunaan Lahan Kecamatan Ampenan Tahun 2017

(Sumber: Hasil Analisis)

\section{Analisa RTRW Kota Mataram}

Berdasarkan hasil potong (clip) Peta Pola Ruang Kota Mataram dengan menggunakan batas Kecamatan Ampenan, maka diperoleh pembagian Zona pola ruang beserta luasnya yang dapat dilihat pada Tabel 3 dan Gambar 3.

Tabel 3

Rencana Pola Ruang Kota Mataram di Kecamatan Ampenan

\begin{tabular}{lrr}
\hline \multicolumn{1}{c}{ RTRW } & Luas (ha) & Pesentase (\%) \\
\hline Resapan Air & 247.80 & 26.22 \\
Pertanian & 0.22 & 0.02 \\
Permukiman & 507.74 & 53.73 \\
Industri & 3.66 & 0.39 \\
Pariwisata & 73.06 & 7.73 \\
Bisnis Perdagangan & 112.42 & 11.90 \\
\multicolumn{1}{c}{ Total } & 944.92 & 100.00 \\
\hline
\end{tabular}

Sumber: RTRW, 2014

Berdasarkan Tabel 3, pembagian Zona dalam Rencana Pola Ruang di Kacamatan Ampenan didominasi oleh Kawasan Permukiman yaitu sekitar $507,74 \mathrm{Ha}$ atau 53,73 \%, sedangkan zona yang paling kecil yaitu berupa Industri yaitu sekitar 3,66 Ha atau 0,39 \% dari total luas wilayah Kecamatan Ampenan. 


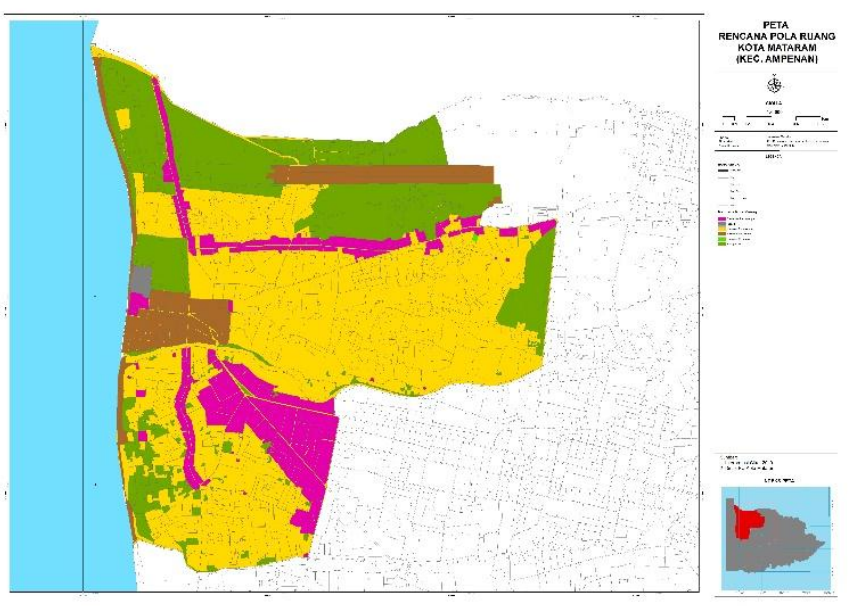

Gambar 3. Peta Rencana Pola Ruang Kecamatan Ampenan Kota Mataram

(Sumber: RTRW, 2014)

\section{Evaluasi Konflik Ruang}

Proses penilaian konflik ruang menggunakan analisis kualitatif, yaitu menilai kesesuaian antara RTRW dangan implementasi pemanfaatan ruang yang teridentifikasi pada data penggunaan lahan. RTRW dinilai "Konsisten" jika terdapat kesesuaian diantara keduanya, "Inkosisten" jika pemanfaatan ruang tidak sesuai dengan RTRW dan diduga akan memberi dampak kerusakan lingkungan yang besar, sedangkan "Netral" jika pemanfaatan ruang tidak sesuai dengan RTRW, akan tetapi tidak memberikan dampak negatif pada kegiatan utama serta lingkungannya [4].

Berdasarkan hasil analisis dengan menggunakan Matriks Konsistensi, maka diketahui bahwa pada tahun 2010, terdapat ruang/lahan yang dinilai bersifat Inkonsistensi yaitu seluas 47,61 Ha atau 5,04 \%, bersifat konsistensi seluas 773,93 Ha atau 81,90 \%, serta yang bersifat Netral seluas 123,38 ha atau 13,06 \%. Sedangkan pada tahun 2017, ruang/lahan yang bersifat inkonsistensi semakin bertambah menjadi $75,41 \mathrm{Ha}$ atau $7,98 \%$, ruang/lahan yang bersifat konsistensi juga bertambah menjadi 793,81 Ha atau $84,01 \%$, sedangkan yang bersifat netral justru berkurang menjadi 75,70 $\mathrm{Ha}$ atau 47,68 \%. Untuk lebih jelasnya, dapat dilihat pada Tabel 4 dan Gambar 4 dan Gambar 5.

Tabel 4

Hasil Evaluasi Konflik Ruang Kecamatan Ampenan

\begin{tabular}{|c|c|c|c|c|c|c|c|}
\hline \multirow{2}{*}{ Evaluasi } & \multicolumn{2}{|c|}{2010} & \multicolumn{2}{|c|}{2017} & \multicolumn{2}{|c|}{ Perubahan } & \multirow{2}{*}{ Keterangan } \\
\hline & $\underline{\text { Luas}(\mathrm{Ha})}$ & $\%$ & Luas(Ha) & $\%$ & Luas(Ha) & $\%$ & \\
\hline Inkonsistensi// & 47.61 & 5.04 & 75.41 & 7.98 & 27.80 & 2.94 & Bertambah \\
\hline Netral & 123.38 & 13.06 & 75.70 & 8.01 & -47.68 & 5.05 & Berkurang \\
\hline $\begin{array}{l}\text { Konsistensi/ } \\
\text { sesuai }\end{array}$ & 773.93 & 81.90 & 793.81 & 84.01 & 19.88 & 2.10 & Bertambah \\
\hline Total & 944.92 & 100.00 & 944.92 & 100.00 & & & \\
\hline
\end{tabular}

Sumber: Hasil Analisis, 2017

Berdasarkan Tabel 4, dapat dilihat bahwa ruang yang bersifat inkonsistensi meningkat sekitar 27,80 Ha atau 2,94\% dari total luas wilayahnya, serta ruang yang bersifat konsistensi juga meningkat sekitar 19,88
Ha atau 2,10 \% dari total luas wilayahnya. Sedangkan ruang yang bersifat netral justru terjadi penurunan luasan sebesar 47,64 Ha atau 5,05 \% dari total luas wilayahnya. Hal ini menunjukan bahwa baik ruang yang bersifat inkonsisten dan konsisten, melakukan ekspansi terhadap ruang yang bersifat netral.

Berdasarkan Permen ATR No.6 Tahun 2017, kegiatan Revisi RTRW akan dilakukan jika muatan rencana berubah kurang dari atau mendekati 20\% [6]. Sehingga dapat disimpulkan bahwa, secara umum implementasi kegiatan pemanfaatan serta pengendalian ruang di Kecamatan Ampenan masih dikategorikan dalam kondisi aman.

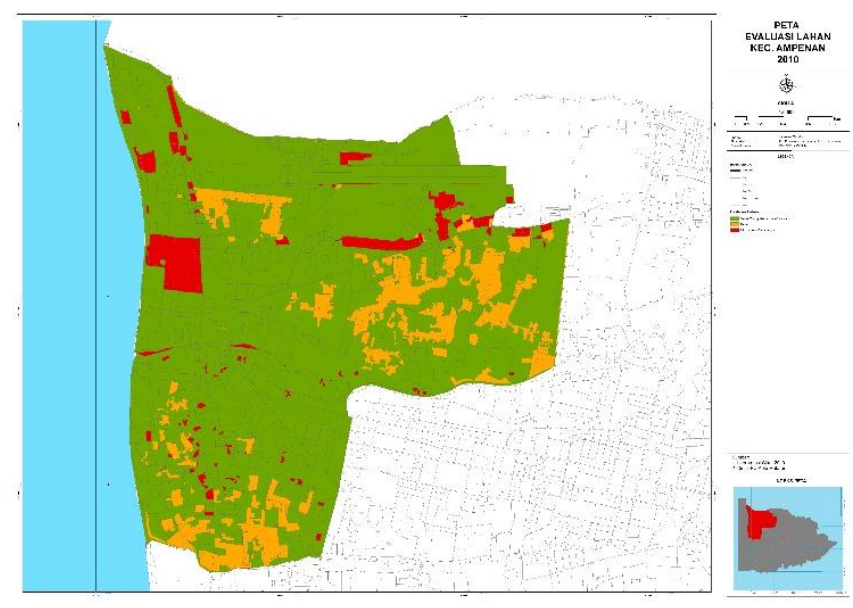

Gambar 4. Evaluasi Konsistensi/Inkonsistensi dan Konlik Ruang Kecamatan Ampenan tahun 2010 (Sumber: Hasil Analisis)

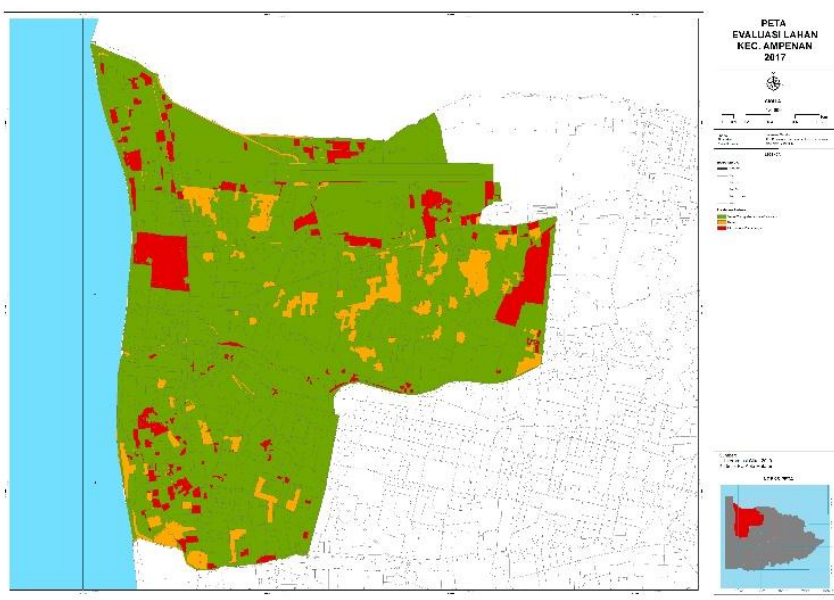

Gambar 5 Peta evaluasi Konsistensi/Inkonsistensi dan Konflik Ruang Kecamatan Ampenan tahun 2017 (Sumber: Hasil Analisis)

\section{SIMPULAN DAN SARAN}

Berdasarkan hasil analisis di atas maka kesimpulan dari Penelitian Kajian Perubahan Fisik Spasial Kawasan Urban Fringe Kota Mataram, studi kasus Kecamatan Ampenan, antara lain:

1. Luasan perubahan fisik spasial Kecamatan Ampenan dari tahun 2010 sampai tahun 2017 adalah \pm 80,49 Ha atau 8,59 \% dari total luas wilayahnya, dimana konversi lahan yang dominan terjadi yaitu berupa 
lahan pertanian (sawah) berubah fungsi menjadi lahan terbangun perkotaan (permukiman dan terbangun non permukiman).

2. Hasil evaluasi konflik ruang dengan menggunakan matrik konsistensi, diperoleh bahwa pada tahun 2010 dan 2017, diperloleh tahun 2010 terdapat $47.61 \mathrm{Ha}$ (5.04 \%) yang bersifat bertentangan/inkonsisten, $123.38 \mathrm{Ha}(13.06 \%)$ yang bersifat nertal, dan 773.93 $\mathrm{Ha}(81.90 \%)$ yang bersifat sesuai/konsisten. Sedangkan pada tahun 2017 terdapat 75.41 $\mathrm{Ha}(7.98 \%)$ yang bersifat bertentangan/inkonsisten, $75.70 \mathrm{Ha}(8.01 \%)$ yang bersifat netral dan $793.81 \mathrm{Ha}$ (19.88 \%) yang bersifat sesuai/konsisten. Sehingga dapat disimpulkan bahwa, secara umum implementasi kegiatan pemanfaatan serta pengendalian ruang di Kecamatan Ampenan masih dikategorikan dalam kondisi aman.

\section{DAFTAR RUJUKAN}

[1] d. Subroto, "Proses Transformasi Spasial dan Sosio Kultural Desa-Desa di Pinggiran Kota (Urban Fringe) di Indonesia (Studi Kasus Yogyakarta)," Laporan Penelitian pengkajian dan Penelitian Ilmu Pengetahuan Dasar TahunAnggaran 1996/1997. PPLH UGM, 1997.

[2] Daldjoeni, Geografi Kota dan Desa, Bandung: Alumni, 1987.

[3] H. S. Yunus, Struktur Tara Ruang Kota, Yogjakarta: Penerbit Pustaka Pelajar, 2000.

[4] M. Lutfi, Penataan Ruang Wilayah dan Kota (Tinjauan Normatif-Teknis), Yogyakarta: Badan Penerbit Fakultas Geografi UGM, 2013.

[5] Rosul.M, "Urban Sprawl (Pemerkaran Kota)," 2008. [Online]. Available: http://mrosul.edublogs.org.

[6] M. A. d. T. R. N. 6/2017, "Tata Cara Peninjauan Kembali Rencana Tata Ruang Wilayah,” Jakarta, 2007.

[7] d. Koesparmadi, Periurban Sebagai Perhatian Kualitas Hidup, Tanggerang Serpong: Redaksi Jurnal Dinamika Periurban-Jurusan Perencanaan Wilayah Kota Institut Teknologi Indonesia, 2005.

[8] H. S. Yunus, Dinamika Wilayah Peri-Urban, Yogyakarta: Penerbit Pustaka Pelajar, 2008. 